CLINICAL HEMORHEOLOGY, Vo1. 3, pp. 331-332, 1981

0271-5198/81/030331-02\$02.00/0 Printed in the USA.

Copyright (c) 1981 Pergamon Press Ltd. All rights reserved.

International Symposium on

HEMORHEOLOGICAL APPROACH TO CARDIOVASCULAR DISEASES

A Satellite Meeting of IVth International Congress of Biorheology

August 3, 1981, National Cardiovascular Center, Osaka, Japan

\title{
SCIENTIFIC PROGRAM
}

\section{INVITED LECTURES}

Chairmen: T. Azuma (Japan) and W.E. Stehbens (New Zealand)

Arterial Fluid Mechanics and Atherogenesis

C.G. Caro (U.K.)

-Short Communication-An Approach to the Transport and Clearance of Blood Components in the Human Aortic Intima

T. Nakashima, A. Tanimura and A. Nakashima (Japan)

Chairmen: Y.C. Fung (U.S.A.) and K. Hayashi (Japan)

Main Determinants of Red Blood Cell Deformability. Clinical and Pharmacological Approaches

J.F. Stoltz (France)

-Short Communication-The Deformability of Cholesterol-Loaded Erythrocyte

K. Shiga (Japan)

Chairmen: A.L. Copley (U.S.A.) and E. Fukada (Japan)

The Proper Phase of Clotting. Its Physical Differentiation by Resonance-Thrombography and Thrombelastography

H.H. Hartert (F.R. Germany)

-Short Communication-Blood Coagulation and its Diagnosis

T. Matsuda (Japan)

Chairman: S. Usami (U.S.A.)

New Hemorheological Techniques for the Routine Laboratory

H. Schmid-Schönbein, E. Volger, P. Teitel, H. Kiesewetter, U. Dauer and L. Heilmann (F.R. Germany)

Contribution of Hemorheology to Clinical Medicine

Chairmen: S. Chien (U.S.A.) and H. Niimi (Japan)

Hemorheology in Clinical Medicine

S. Chien (U.S.A.) 
Microrheology and Clinical Medicine: Unravelling Some Problems Related to Thrombosis

H.L. Goldsmith and T. Karino (Canada)

Chairmen: A.M. Ehrly (F.R. Germany) and R. Nakayama (Japan)

Measuring and Assessing Therapeutical Effects and Efficacy of Rheological Acting Drugs in Vascular Diseases

A.M. Ehrly (F.R. Germany)

Blood Rheology and Oxygen Supply to Tissue

P.S. Lingard (Australia)

The Role of Blood Viscosity in Hypertension

T. Natsume, M. Tsuchiya, A. Sakaguchi, R. Nakayama and M. Ikeda (Japan)

Nonuniform Sympathetic Nervous Control of Small Arteries in Various Organs

I. Ninomiya, S. Hirata, S. Suehiro and Y. Okada (Japan)

Studies on the Flow Pattern in the Pulmonary Trunk with a Combined Doppler and Two-Dimensional Echocardiography from the Transcutaneous Approach

Y. Nimura, N. Kinoshita, K. Miyatake, M. Okamoto and H. Sakakibara (Japan)

Movie Session

Chairmen: W.M. Phillips (U.S.A.) and M. Sugawara (Japan)

Non-invasive Visualization of Intracardiac Blood Flow in Human Heart Using Pulse Doppler Technique

A. Kitabatake, M. Inoue, M. Asao et al (Japan)

Quantitative Analysis of Capillary Topography and Distribution in Heart and Brain of Cats: Intravital Microscopic Study

T. Yamakawa, J. Nuccio, B. Chang and R.J. Bing (U.S.A.)

Flow structure in Microvessels in Relation to Vascular Diseases

H. Niimi, S. Hanai, M. Minaniyama and T. Yamakawa (Japan)

Flow Disturbance at Branching Sites in Abdominal Aorta

T. Fukushima and T. Azuma (Japan)

Closing Remarks

R. Nakayama (Japan)

NOTE: The proceedings of the Satellite Meeting will be published this year in Supplement 1 of CLINICAL HEMORHEOLOGY. 